American Journal of Agricultural and Biological Sciences 4 (4): 319-331, 2009

ISSN 1557-4989

(C) 2009 Science Publications

\title{
The Yellow Mealworm as a Novel Source of Protein
}

\author{
${ }^{1}$ A.E. Ghaly and ${ }^{2}$ F.N. Alkoaik \\ ${ }^{1}$ Department of Biological Engineering, Dalhousie University, Halifax, Nova Scotia, Canada \\ ${ }^{2}$ Department of Agricultural engineering, College of Food and Agricultural Sciences, \\ King Saud University, Riyadh, Kingdom of Saudi Arabia
}

\begin{abstract}
Problem statement: Yellow mealworms of different sizes (4.8-182.7 mg) were grown in a medium of wheat flour and brewer's yeast (95:5 by weight) to evaluate their potential as a protein source. Approach: There was an initial adjustment period (3-9 days) observed during which the younger larvae $(4.8-61.1 \mathrm{mg})$ grew slowly while the older ones $(80.3-182.7 \mathrm{mg})$ lost weight. After this initial period, the younger larvae $(4.8-122.1 \mathrm{mg})$ increased in weight while the older ones (139.6-182.7 $\mathrm{mg}$ ) continued to lose weight as they entered the pupal stage. For efficient production of larvae, they should be harvested at a weight of 100-110 mg. The moisture issue in the medium presents an important management problem for commercial production. Results: A system in which eggs are separate from adults and hatched in separate chambers would alleviate the danger of losing the larval population due to microbial infection. The moisture, ash, protein and fat contents were 58.1-61.5, 1.8$2.2,24.3-27.6$ and $12.0-12.5 \%$, respectively. Yellow mealworms seem to be a promising source of protein for human consumption with the required fat and essential amino acids. Further research into raising them on a variety of low quality substances/wastes such as saw dust, waste paper, corn starch and potato flour is recommended. Conclusion/Recommendations: The future research should also investigate the nutrition content of the medium (minerals, protein, fat, carbohydrates and vitamins) and the effect of environmental parameters (temperature, humidity, production of $\mathrm{CO}_{2}$ and heat) on protein yield and quality. This information will aid in the design of an economically viable large scale production system.
\end{abstract}

Key words: Entomophagy, insects, yellow mealworm, wheat flour, yeast, growth rate, protein, amino acids, fat, essential elements, human food, fat, protein

\section{INTRODUCTION}

About two-thirds of the world's population suffered from protein deficiency in the 1970 ' ${ }^{[1]}$. The development of novel protein sources such as Fish Protein Concentrate (FPC) ${ }^{[2-4]}$ and Single Cell Protein $(\mathrm{SCP})^{[5,6]}$ has made a major contribution to the world protein pool. However, there is still over one billion people suffering from malnutrition and protein deficiency today ${ }^{[7]}$. It is, therefore, conceivable that similar success could be obtained by utilizing what seems to be an inexhaustible source of insects to provide a sustainable supply of protein for human consumption. Insects can be reared on low substrate or waste materials as they are efficient converters of feed to protein. Careful processing and marketing procedures would make the Insect Protein (IP) as acceptable as FPC and SCP.

Entomophagy, the art of eating insects, has been practiced since the dawn of man and several insect species have been utilized as food in many parts of the world $^{[8,9]}$. Locusts have been eaten with gusto in Arabia, Persia, Madagascar, Africa and India ${ }^{[0]}$. They are prepared by a variety of methods: some people grind and bake them into cakes, others fry and season them with salt and pepper, while others boil them causing the insects to turn red like lobsters ${ }^{[8-10]}$. Next to the locusts, termites are the second most popular insect food. Because of their importance in some regions of South America and Africa, termite colonies are often staked out as the private property of individuals or groups in these parts of the world ${ }^{[9]}$. Another form of insect that finds its way to many tables is the grub. For example, enormous larvae of the palm weevil are extracted from the palm trees and eaten in the West Indies under the name of "grugru" ${ }^{10]}$. Other insects that commonly form the main constituents of human meals for some cultures are cockroaches, praying mantis, lice, stink bugs, dragonflies, moths, ants, fleas and spiders ${ }^{[8-10]}$.

Corresponding Author: A.E. Ghaly, Department of Biological Engineering, Dalhousie University, Halifax, Nova Scotia, Canada Tel: (902) 494-6014 
Am. J. Agri. \& Biol. Sci., 4 (4): 319-331, 2009

Table 1: Maximum permissible levels of insect infestation or damage ${ }^{[12]}$

\begin{tabular}{ll}
\hline Product & Maximum level \\
\hline Coffee beans & $10 \%$ by count insect infested or insect damaged \\
Cherries (fresh, canned or frozen) & $4 \%$ by count insect infested \\
Citrus fruit juices (canned) & 5 per $250 \mathrm{~mL}$ Drosophilia and other fly eggs or 1 maggot per $250 \mathrm{~mL}$ \\
Peanut butter & 30 insect fragments per $100 \mathrm{~g}$ \\
Asparagus (canned or frozen) & $10 \%$ of spears by count infested with 6 attached asparagus beetle eggs or egg sacs \\
Spinach (canned or frozen) & 8 spinach leaf miners per $100 \mathrm{~g}$ or 4 leaf miners $3 \mathrm{~mm}$ or more in length per $100 \mathrm{~g}$ \\
Tomato puree & 20 fruit fly eggs per $100 \mathrm{~g}$, or 10 fruit fly eggs and 1 maggot per $100 \mathrm{~g}$ or 2 maggots per $100 \mathrm{~g}$ \\
\hline
\end{tabular}

Table 2: Protein and fat content of various organisms ${ }^{[9,14]}$

\begin{tabular}{lcr}
\hline Organism & Protein $(\%)$ & Fat $(\%)$ \\
\hline Conventional foods & & \\
Beef & 18.4 & 20.5 \\
Lamb & 15.4 & 27.1 \\
Pork & 14.6 & 31.4 \\
Chicken & 22.0 & 3.8 \\
Fish & 18.3 & 10.0 \\
Insects & & \\
Termites & 23.3 & 28.3 \\
Caterpillars & 38.1 & 13.7 \\
Adult weevils & 30.3 & 2.3 \\
House fly pupae & 63.1 & 15.5 \\
May beetle larvae & 11.1 & 3.1 \\
Adult female ants & 7.4 & 23.8 \\
Adult male ants & 25.2 & 3.3 \\
Bee & 18.1 & 15.5 \\
Silkworm & 23.1 & 14.2 \\
Grasshopper & 46.1 & 2.4 \\
\hline
\end{tabular}

Entomophagy is not, however, widely practiced in western culture $^{[11]}$ and because of the difficulty of removing all insect fragments from food products, most governments set maximum allowable legal levels. The USA maximum permissible levels in some foods are presented in Table $1^{[12]}$. However, the consumer has probably ingested insects on several occasions as insects are practically omnipresent within all consumed foods of plant origin ${ }^{[13]}$. DeFoliart ${ }^{[11]}$ stated that many of us have already eaten insects without realizing it. For example red scale insects are used as a coloring agent in Smarties and yoghurt.

The composition of a few of the more commonly consumed insects (Table 2) shows their potential as a protein source as compared to traditional foods ${ }^{[9,14]}$. Booram et $a l .^{[15]}$ reported that the larvae of the fly Hermetia illucens consisted of $35 \%$ crude fat and $42 \%$ crude protein and concluded that these larvae could have a future as an alternate source of protein. House fly larvae were suggested as a possible source of protein $^{[14,16]}$. Taylor ${ }^{[9]}$ reported that the protein contained in termites and house fly larvae is similar to animal proteins in terms of amino acids present. Steinhouse ${ }^{[17]}$ stated that the day may come when the nutritious elements (especially protein) of common and readily available insects will be utilized to supplement the world's food needs. Indeed, when organisms such as bacteria and yeast (SCP) grown on chemical residues, petroleum by products and other fibrous residues can be rendered acceptable, the step to use insects as a food source will represent substantial innovation in food technology $y^{[1,11,18-20]}$.

Many reports about the taste of insects have been recorded. Taylor ${ }^{[9]}$ conducted a casual taste panel using commercially available canned foods consisting of various insect forms. Fried ants were described as insipid because they lacked distinct taste. Fried agave worms were compared to slightly burned French fries. Predaceous diving beetles were quite good and were compared to clams, sunflower seeds and shrimps. Fried grasshoppers were found quite acceptable and were said to taste like fish. Bees were described as having a strong disagreeable flavor and too mushy. Fried silkworms were likened to rotten meat. Fried butterflies were said to taste like the pier smells. Fried caterpillars provided such comments as putrid and horrible. Fresh insects, on the other hand, enjoyed more popularity. Bodenheimer $^{[8]}$ reported that cockchafer worms steeped in vinegar, rolled in flour and fried were readily acceptable at a banquet given in Paris for the purpose of evaluating this insect's flavor. Holt ${ }^{[10]}$ stated that raw grasshoppers were pleasant to taste and delicious when cooked. Taylor ${ }^{[9]}$ reported that termites tasted like lobsters, with a strong suggestion of snail. Hyde ${ }^{[21]}$ noted that stir-fried pupae of silkworm were delicious and added a protein rich supplement and pleasant flavor to vegetarian diets in China. Giroux ${ }^{[22]}$ reported that the giant water bug Lethocerus indicus had a good flavor and was considered a true delicacy in south-western China and Southeast Asia.

Objectives: Very little information is available on the nutritional quality of the mealworms. The ease with which they can be reared and handled makes them an ideal population to study on a small scale. The aim of this study was to evaluate the yellow mealworm (Tenebrio molitor) as a potential human food. The specific objectives were: (a) to establish a strong culture of yellow mealworms, (b) to evaluate the growth characteristics and life cycle of the yellow mealworms, and (c) to evaluate the nutritional composition of the yellow mealworms for use as human food. 


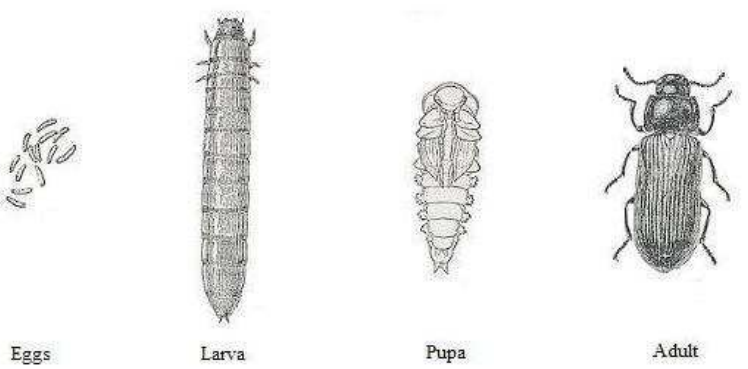

Fig. 1: The yellow mealworm (Tenebrio molitor $)^{[24]}$

Yellow mealworm:

Distribution: The yellow mealworm (Tenebrio molitor) is distributed throughout the world. It is referred to as the European mealworm and is a member of the order Coleoptera of the family Tenebrionidae ${ }^{[23]}$. It is widely distributed in Canada in the provinces of British Columbia, Alberta, Saskatchewan, Manitoba, Ontario, Quebec, New Brunswick, Nova Scotia and Prince Edward Island $^{[24]}$. The species normally overwinters in the larval stage and pupation occurs in spring and early summer at which time adults begin to appear ${ }^{[25]}$.

Habitats and feeding: The yellow mealworm is of a moderate importance as a pest in stored grains and milled products and is found in feed buildings throughout Canada. They prefer decaying grains and milled cereals that are moist but can also feed on products that are not decaying such as meal, flour, bran, grain, course cereals, bread, crackers, mill sweepings, meat scraps, feathers and dead insects ${ }^{[23]}$. The larvae usually attach the embryo, eating the softer parts of the grain, while the adults often kill and feed on other insects found in the medium ${ }^{[24]}$. The insect is most often found in and around dark and damp places, grain bins, sacks of feed, litter of chickens, bird houses, mills, grain elevators, feed processing plants and warehouses $^{[26,27]}$.

Commercial use: The larvae are best known as fish bait and as food for fish, amphibians, reptiles, turtles, birds, fowls and small mammals kept as house hold pets or in zoos. They are named as the best animal protein feeding stuff and reared in enormous quantities in small scale operations throughout the world for these uses $^{[28,29]}$. Taylor ${ }^{[9]}$ and Holt ${ }^{[10]}$ reported the use of mealworms in a large scale as human food in many countries in Europe and Asia.

Life cycle: A complete life cycle of the yellow mealworm (Fig. 1) includes: Egg, larva, pupa and adult $^{[24]}$. The female deposits from 250-1000 eggs with an average of 400-500 eggs. The eggs are bean shaped, sticky, shiny white in color. The eggs are laid singly or in clusters in the food material. They range in length from $1.7-1.8 \mathrm{~mm}$ and in width from $0.6-0.7 \mathrm{~mm}$. The incubation period of the eggs is highly influenced by temperature with the optimum being 2 weeks at $25^{\circ} \mathrm{C}$.

In about 2 weeks, the eggs hatch into larvae. The larva is white in color and about $2 \mathrm{~mm}$ long. It turns bright yellowish brown upon feeding. The larva is elongated cylinder with 6 small legs right behind the head and 2 short horn like appendages on the tips of the abdomen. The larval stage lasts 6-8 months under optimum conditions and can reach 2 years if the environment is not suitable. During this period, larva reaches a length of $2.0-2.5 \mathrm{~cm}$ and turns white in color. Mature larvae wander in large numbers into unusual places in search for a suitable location to pupate.

In pupal stage, the larvae turn yellowish in color with a length of $1 \mathrm{~cm}$. They are soft, immobile and relatively unprotected due to the absence of a pupal case found in many other species of insects. The pupal stage is highly influenced by temperature and can range from 6 days at $28-18$ days at $18^{\circ} \mathrm{C}$.

The hard shelled adult beetles emerging from the pupae are shiny brown black in color and about $1 \mathrm{~cm}$ in length. The life span of the adult ranges from 37-96 days. Mating takes place within a few days of the emergence and is repeated at intervals throughout the life of the adults.

\section{MATERIALS AND METHODS}

Mealworms: One hundred mealworms (at different stages of growth) were purchased from a local pet store in Halifax, Nova Scotia. They were obtained in a small plastic container $(45 \mathrm{~cm}$ long $\times 25 \mathrm{~cm}$ wide $\times 15 \mathrm{~cm}$ deep) which had a perforated plastic cover. The larvae were raised in the pet store on a commercial feed made of wheat germs and oatmeal.

Growth medium: Gibson ${ }^{[29]}$ and Lyon ${ }^{[30]}$ suggested using a feed medium made of wheat flour and wheat bran or oatmeal and corn bran with raw fresh vegetables added (such as carrots, potatoes or lettuce) to provide the needed moisture. The growth medium used in this study was made from whole wheat flour ( $95 \%$ by weight) and brewer's yeast ( $5 \%$ by weight). Shredded paper towel was added to prevent the medium from packing too solidly and to facilitate the movement of the larvae. The prepared growth medium was placed In a plastic container $(60 \mathrm{~cm}$ long $\times 45 \mathrm{~cm}$ wide $\times 25$ $\mathrm{cm}$ deep) having a perforated plastic cover. Slices of potatoes were placed in small shallow aluminum dishes and the dishes were placed on the top of the growth medium to provide the vitamin and calcium supplements and the additional moisture required by the adults. 
Am. J. Agri. \& Biol. Sci., 4 (4): 319-331, 2009

Table 3: Weight of larvae used in the study

\begin{tabular}{|c|c|c|c|c|c|c|c|c|c|c|c|c|}
\hline \multirow{2}{*}{ Groups } & & \multicolumn{11}{|c|}{ Weight $(\mathrm{mg})^{*}$} \\
\hline & 1 & 2 & 3 & 4 & 5 & 6 & 7 & 8 & 9 & 10 & Average & Ranges \\
\hline 1 & 4 & 5 & 5 & 5 & 4 & 6 & 5 & 4 & 4 & 5 & 4.8 & $4-6$ \\
\hline 2 & 18 & 16 & 14 & 15 & 15 & 18 & 14 & 17 & 17 & 16 & 16.0 & $14-18$ \\
\hline 3 & 41 & 40 & 40 & 41 & 44 & 40 & 41 & 44 & 43 & 44 & 41.4 & $40-44$ \\
\hline 4 & 63 & 60 & 60 & 60 & 60 & 59 & 64 & 59 & 65 & 61 & 61.1 & $59-65$ \\
\hline 5 & 79 & 77 & 78 & 75 & 78 & 83 & 81 & 78 & 85 & 79 & 80.3 & $78-85$ \\
\hline 6 & 100 & 103 & 105 & 101 & 105 & 100 & 105 & 103 & 100 & 101 & 103.0 & $100-105$ \\
\hline 7 & 121 & 118 & 125 & 118 & 123 & 122 & 121 & 122 & 118 & 123 & 121.1 & $118-125$ \\
\hline 8 & 140 & 142 & 138 & 141 & 138 & 139 & 139 & 138 & 143 & 138 & 139.6 & $138-143$ \\
\hline 9 & 160 & 165 & 159 & 164 & 159 & 160 & 158 & 164 & 160 & 166 & 161.5 & $158-166$ \\
\hline 10 & 182 & 186 & 180 & 186 & 180 & 180 & 179 & 185 & 184 & 185 & 182.7 & $179-186$ \\
\hline
\end{tabular}

Culture preparation: The larvae were separated from the commercial feed material using a small kitchen sifter and placed on the prepared growth medium in the plastic container. The container was covered with the perforated plastic cover and placed in a controlled environmental chamber (VWR Environmental Chamber, Model No. 2020, Shelden Manufacturing Company Inc. Cornelius, Oregon) at $25^{\circ} \mathrm{C}, 70 \%$ relative humidity and photoperiodic regime of $8 \mathrm{~h}$ light and $16 \mathrm{~h}$ darkness. A little bran was sprinkled on the surface of the medium and a few pieces of potatoes were added every 3 days. Some adults appeared in the culture shortly after preparation as many of the larvae seemed to have pupated before starting the experiment. Eggs started to hatch after 30 days and minute larvae were found on the potatoes. The eggs continued to hatch for 2 months yielding a substantial supply of mealworms of various ages and sizes (weights).

Growth experiment: In order to study the growth characteristics of yellow mealworms, the growth experiment was carried out using 10 groups of larvae, each having 10 larvae of similar weights as shown in Table 3. Each group was placed in a separate plastic container $(65 \mathrm{~cm}$ long $\times 45 \mathrm{~cm}$ wide $\times 25 \mathrm{~cm}$ deep $)$ containing a diet of whole wheat flour and yeast (95:5 by weight). The containers were covered with perforated plastic covers and placed in a controlled environmental chamber (VWR Environmental Chamber, Model No. 2020, Sheldon Manufacturing Inc, Cornelius, Oregon) at $25^{\circ} \mathrm{C}, 70 \%$ relative humidity and photoperiodic regime of $8 \mathrm{~h}$ of day light and $16 \mathrm{~h}$ of darkness. A little bran was sprinkled on the surface of the medium every 3 days. The experiment lasted 33 days during which the worms in each container were weighted every 3 days and the changes in the groups were observed and recorded.
Nutrition analysis: The moisture, ash, protein and fat contents of mealworms representing a full range of weights (4.8-182.7 $\mathrm{mg}$ ) were carried out.

Moisture content: The moisture content was determined gravimetrically using 50 live worms (5 from each weight group). The oven dry method procedure described in $\mathrm{APHA}^{[31]}$ was followed. The 50 live worms were first weighed (in groups of 5 worms) using a Mettler scientific balance (AEZOOS, Mettler Instruments, AG, Greifensee-Zurich, Switzerland). They were then dried in a convection oven (Isotemp oven, Model No. 655F, Fisher Scientific, Montreal, Quebec) for $24 \mathrm{~h}$ at $105^{\circ} \mathrm{C}$. The dried worms were then removed from the oven, left to cool in a dessicator and weighed. The moisture content was calculated as follows:

$\mathrm{MC}=\frac{\mathrm{M}_{1}-\mathrm{M}_{2}}{\mathrm{M}_{1}} \times 100$

Where:

$\mathrm{MC}=$ The moisture content $(\% \mathrm{wb})$

$\mathrm{M}_{1}=$ The weight of live worms (mg)

$\mathrm{M}_{2}=$ The weight of the dried worms (mg)

Ash content: The ash content was determined gravimetrically on live weight basis according to the procedure described in $\mathrm{APHA}^{[31]}$. The dried worms (5 from each weight group) were placed in a muffle furnace (Isotemp muffle furnace, Model No. 186A, Fisher Scientific, Montreal, Quebec) for $30 \mathrm{~min}$ at $550^{\circ} \mathrm{C}$. They were then removed, left to cool in a dessicator and weighed using a Mettler scientific balance (AEZOOS, Mettler Instruments, AG, Greifensee, Zurich, Switzerland). The ash content was calculated as follows: 
$\mathrm{AC}=\frac{\mathrm{M}_{3}}{\mathrm{M}_{1}} \times 100$

Where:

$\mathrm{AC}=$ The ash content $(\% \mathrm{wb})$

$\mathrm{M}_{3}=$ The weight of the ash remaining after burning the dry worms $(\mathrm{mg})$

Protein content: The protein analysis was carried out on live weight basis using 50 worms (5 from each weight group). The live weight of each group (5 worms) was recorded using a Mettler scientific balance (AEZOOS, Mettler Instruments, AG, Greifensee, Zurich, Switzerland). The worms were subsequently frozen and dried in a freeze dryer (Labconco FreeZone, Cat No. 10-271-16, Fisher Scientific, Montreal, Quebec) for $24 \mathrm{~h}$. Each group was ground using a laboratory grinder (Waring Laboratory, Cat No. 14509-18, Fisher Scientific, Montreal Quebec). The total protein was determined using the Tecator Kjeltec Auto Analyzer (Model-1026, Fisher Scientific, Montreal, Quebec). The ground material from the five freeze dried mealworms was transferred to the macro $250 \mathrm{~mL}$ digestion tubes. One "Kjeltab" (containing $3.5 \mathrm{~g} \mathrm{~K}_{2} \mathrm{SO}_{4}$ and $0.0035 \mathrm{~g} \mathrm{Se}$ ) and $3.0 \mathrm{~mL}$ of distilled water were added to the samples in the digestion tubes. The samples were digested at $420^{\circ} \mathrm{C}$ for $30 \mathrm{~min}$ in a digestion block heater (Tecator Digester System, 20 Model-1016, Fisher Scientific, Montreal, Quebec). The digestion tubes were removed and allowed to cool for $10 \mathrm{~min}$. Then, $30 \mathrm{~mL}$ of distilled water was added to each of the digestion tubes. The tubes and the digests were transferred to the Auto Analyzer. The constants A and $\mathrm{B}$ for the equipment were set at 0.00 and 1.862, respectively. The titrant acid and the predetermined blank sample were set at 0.2127 and $0.01 \mathrm{M}$, respectively. Distillation, titration and calculation were performed automatically. The protein percentage was computed from the following equation:

$\mathrm{PC}=\frac{\text { Displayed results }}{\mathrm{W}_{\mathrm{s}}}$

Where:

$\mathrm{PC}=$ The protein content $(\% \mathrm{wb})$

$\mathrm{W}_{\mathrm{s}}=$ The weight of the sample of live worms $(\mathrm{g})$

Fat content: The fat content was carried out on live weight basis using 50 worms (5 from each weight group). The live weight of each group (5 worms) was recorded using a Mettler scientific balance (AEZOOS, Mettler Instruments, AG, Greifensee, Zurich,
Switzerland). The worms were then frozen and dried in a freeze dryer (Labconco FreeZone, Cat No. 10-271-16, Fisher Scientific, Montreal, Quebec) for $24 \mathrm{~h}$. Each group was ground in a laboratory grinder (Waring Laboratory, Cat No. 14-509-18, Fisher Scientific, Montreal Quebec. The fat content was determined using an ether extraction technique according to the procedure described in the Official Method of the Association of Official Analytical Chemists ${ }^{[32]}$. Hot ether was percolated through a porous receptacle filled with the ground material from the five freeze dried mealworms for $24 \mathrm{~h}$. The fat was released from the dry matter and collected in a flask at the bottom of the apparatus. The receptacle was removed, dried in an oven (Isotemp oven, Model No. 655F, Fisher Scientific, Montreal, Quebec) for $24 \mathrm{~h}$ at $105^{\circ} \mathrm{C}$ and then reweighed. The change in weight corresponded to the fat content of the original sample (5 worms). The fat percentage was computed from the following equation:

$\mathrm{FC}=\frac{\mathrm{W}_{\mathrm{f}}}{\mathrm{W}_{\mathrm{s}}} \times 100$

Where:

$\mathrm{FC}=$ The fat content $(\% \mathrm{wb})$

$\mathrm{W}_{\mathrm{f}}=$ The weight of extracted fat $(\mathrm{g})$

Amino acid profile: The amino acids (alanine, arginine, cysteine, glutamic, glycine, histidine, isoleucine, leucine, lysine, methionine, phenylalanine, serine, threonine, tryptophan, tyrosine, and valine) were determined using the HFB-IBA (Heptafluorobutyric isobutyl esters of amino acids) Amino Acid Derivatization Kit (Cat. No. 18094, Alltech Associates, Inc., Deerfield, Illinois). First, $50 \mathrm{mg}$ of dried mealworms were weighed using a Mettler scientific balance (AEZOOS, Mettler Instruments, AG, Greifensee, Zurich, Switzerland) and placed in a small reaction vial. An amount of $3 \mathrm{~mL}$ of $0.2 \mathrm{M} \mathrm{HCl}$ was added to each vial and the solutions were heated to approximately $110^{\circ} \mathrm{C}$ using a block heater (Model 16500-10, Hach Chemical Co., Loveland, CO) for $30 \mathrm{~h}$. Then, the vials were removed from the heater and dried under a stream of dry nitrogen. $1.25 \mathrm{~mL}$ of acetyl chloride (Cat. No. 18094B, Alltech Associates Inc. Deerfield, Illinois) were slowly added to $50 \mathrm{~mL}$ of isobutanol and the mixture was added to each vial (which contained dry sample). The vials were capped and heated at $110^{\circ} \mathrm{C}$ for $45 \mathrm{~min}$. The vials were uncapped and heated at $115^{\circ} \mathrm{C}$ under a stream of nitrogen to remove excess reagent. Then, the vials were removed from the heater and cooled in an ice bath 
(Microprocessor Controlled 280 Series Water Bath, Precision, Winchester, Virginia) for approximately 5 min. $3 \mathrm{~mL}$ of methylene chloride and $2 \mathrm{~mL}$ of HFBA (Cat. No. 18094A, Alltech Associates Inc, Deerfield, Illinois) were added to each vial. The vials were then capped and heated at $100^{\circ} \mathrm{C}$ for $4 \mathrm{~h}$. The vials were removed from the heater and after cooling to ambient temperature, excess reagent was evaporated under a stream of dry nitrogen. The dried samples were redissolved by adding $2 \mathrm{~mL}$ of ethyl acetate and injected into the gas chromatograph (Model-HP5890 Series II, Hewlett, Palo Alto, CA). The amino acids profile was determined from the output of the gas chromatograph.

\section{RESULTS}

Culture structure: The changes among the individual worms in each group were observed and recorded. These changes were of three types: (a) death of one or more of the worms, (b) pupation of one or more of the worms and (c) the emergence of adults from pupal stage. The dead worms were counted and discarded. The number of worms to enter the pupal stage of their development and the number of adults emerging from the pupal stage were recorded for each group. The time of pupation of the larvae and the emergence of adults from the pupation stage are shown in Table 4 along with the number of pupae and adults. The results in Table 5 show the larval mortality, pupation and emergence of adults. The mortality was only observed in older groups of larvae (8-10) which had average weights in the range of 139.0-182.7 mg. Only one larva died in each of these three groups (about $10 \%$ mortality). Their death may have been a result of microbial infection.

Members of the older groups 6-10 (103.0-182.7 mg) started the pupation stage at different times. Two larvae in group 6 started pupation on day 30. One larva in group 7 started pupation on day 27 , followed by another 2 larvae on day 30 and 2 more larvae on day 33. One larva in group 8 started pupation on day 21 followed by another larva on day 24, another larva on day 30 and 3 more larvae on day 33. Three larvae in group 9 started pupation on day 12 followed by another 5 larvae on day 15 and another larva on day 24. One larva in group 10 started pupation on day 9 followed by another 2 larvae on day 12 and 6 more larvae on day 15 .

Emergence of adults was observed only for groups 8-10 with 2, 9 and 9 adults, respectively. Emergence of the first adult in group 8 was observed on day 30 followed by another adult on day 33. The emergence of the first adult in group 9 was observed on day 21 followed by another 2 adults on day 24, one adult on day 30 and 5 more adults on day 33. The emergence of the first adult in group 10 was observed on day 18 followed by another adult on day 21, another 3 adults on day 24 and 4 more adults on day 30 .

It is clear from the results (Table 4) that the older the larvae (the greater the weight) the closer to pupation and emergence of adults they were. Figure 2 shows the make up of the population of each group during the 33 day growth period. Groups 1-5 had a population made only of larvae. Groups 6 and 7 had mixed populations of larvae and pupae. Groups 8-10 had mixed populations of larvae, pupae and adults.

Growth, pupation and emergence of adults: Changes in the average weight of the larvae in each group are presented in Table 4 . The 10 groups studied represented different ages of the larvae covering a wide range of weights $(4.8-182.7 \mathrm{mg})$. It is clear from the results that the 10 groups could be divided into 3 sets as shown in Fig. 3.

Table 4: Changes in group (weight, pupation and emergence of adults)

\begin{tabular}{|c|c|c|c|c|c|c|c|c|c|c|}
\hline \multirow{2}{*}{ Day } & \multicolumn{10}{|c|}{ Average weight of each group (mg) } \\
\hline & 1 & 2 & 3 & 4 & 5 & 6 & 7 & 8 & 9 & 10 \\
\hline$\overline{0}$ & 4.8 & 16 & 41.4 & 61.1 & 80.3 & 103.3 & 121.1 & 139.6 & 161.5 & 182.7 \\
\hline 3 & 4.9 & 16.2 & 41.9 & 62.3 & 78.6 & 100.0 & 120.0 & 137.4 & 158.3 & 178.6 \\
\hline 6 & 5.4 & 17.8 & 42.7 & 65.2 & 76.6 & 101.1 & 125.1 & 136.4 & 156.3 & 166.6 \\
\hline 9 & 5.6 & 18.5 & 44.3 & 73.7 & 78.8 & 102.6 & 135.5 & 135.8 & 149.0 & $154.6^{(1 \mathrm{P})}$ \\
\hline 12 & 5.8 & 20.4 & 47.5 & 74.9 & 82.6 & 108.8 & 139.6 & 134.8 & $143.6^{(3 \mathrm{P})}$ & $144.9^{(3 \mathrm{P})}$ \\
\hline 15 & 6.8 & 22.0 & 52.1 & 76.0 & 91.2 & 114.3 & 130.6 & 132.3 & $136.5^{(8 \mathrm{P})}$ & $133.7^{(9 \mathrm{P})}$ \\
\hline 18 & 7.2 & 25.0 & 53.6 & 78.2 & 95.6 & 116.7 & 125.6 & 125.6 & $129.9^{(8 \mathrm{P})}$ & $125.0^{(8 \mathrm{P}+1 \mathrm{~A})}$ \\
\hline 21 & 9.6 & 31.0 & 57.4 & 81.6 & 100.3 & 118.2 & 120.9 & $114.0^{(1 \mathrm{P})}$ & $120.0^{(7 \mathrm{P}+1 \mathrm{~A})}$ & $114.0^{(7 \mathrm{P}+2 \mathrm{~A})}$ \\
\hline 24 & 11.6 & 35.0 & 62.4 & 88.1 & 104.4 & 120.0 & 114.6 & $106.0^{(2 \mathrm{P})}$ & $114.5^{(6 \mathrm{P}+3 \mathrm{~A})}$ & $103.0^{(4 \mathrm{P}+5 \mathrm{~A})}$ \\
\hline 27 & 12.2 & 40.0 & 68.5 & 96.1 & 110.4 & 127.6 & 110.0 & $100.0^{(2 \mathrm{P})}$ & $105.0^{(6 \mathrm{P}+3 \mathrm{~A})}$ & $92.0^{(4 \mathrm{P}+5 \mathrm{~A})}$ \\
\hline 30 & 14.2 & 46.0 & 77.7 & 105.2 & 117.8 & $130.1^{(2 \mathrm{P})}$ & 102.0 & $90.6^{(2 \mathrm{P}+1 \mathrm{~A})}$ & $96.6^{*} 5^{(\mathrm{P}+4 \mathrm{~A})}$ & $82.0^{(9 \mathrm{~A})}$ \\
\hline 300 & 19.1 & 53.0 & 87.5 & 118.0 & 125.3 & $133.0^{(2 \mathrm{P})}$ & 101.0 & $79.0^{(4 \mathrm{P}+2 \mathrm{~A})}$ & $89.0^{(9 \mathrm{~A})}$ & $72.1^{(9 \mathrm{~A})}$ \\
\hline
\end{tabular}


Table 5: Larval mortality, pupation and emergence of adults

\begin{tabular}{lclll}
\hline Group & Average weight $(\mathrm{mg})$ & Dead worms & Pupae & Adults \\
\hline 1 & 4.8 & 0 & 0 & 0 \\
2 & 16.0 & 0 & 0 & 0 \\
3 & 41.4 & 0 & 0 & 0 \\
4 & 61.1 & 0 & 0 & 0 \\
5 & 80.3 & 0 & 0 & 0 \\
6 & 103.0 & 0 & 2 & 0 \\
7 & 121.1 & 0 & 5 & 1 \\
8 & 139.6 & 1 & 6 & 2 \\
9 & 161.5 & 1 & 9 & 9 \\
10 & 182.7 & 1 & 9 & 9 \\
\hline
\end{tabular}

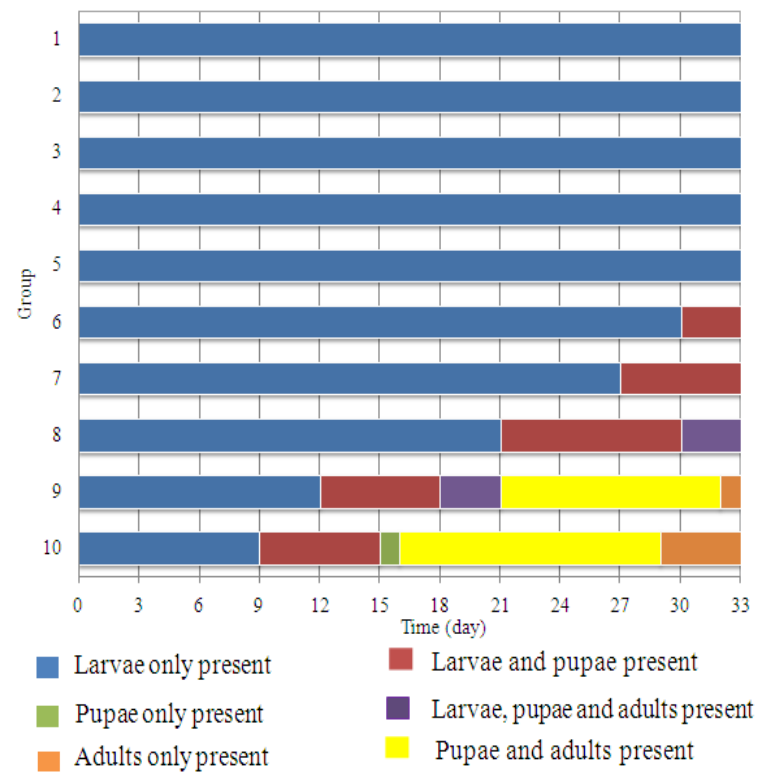

Fig. 2: Changes in population structure

The first set included groups 1-4 which had younger larvae $(4.8-61.1 \mathrm{mg})$. These larvae appeared to have an initial period of adjustment ( 3 days) to the new environment and new diet. There was a slow increase in the weight during this initial period. After the initial period, the weight of the larvae appeared to increase at a much faster rate.

The second set included groups 5-7 which had middle age larvae (80.3-121.1 mg). A much longer initial period (9 days) for adjustment to environmental conditions and new diet was noticed. However, there was weight loss observed during this period for these groups. Adjusting to new diet appeared to be harder for middle age larvae. After the initial period, groups 5 and 6 continued to increase in weight while group 7 (the oldest among the three groups) increased slightly in weight from day 9 till day 12 and started to lose weight as some members of this group entered the pupation stage.
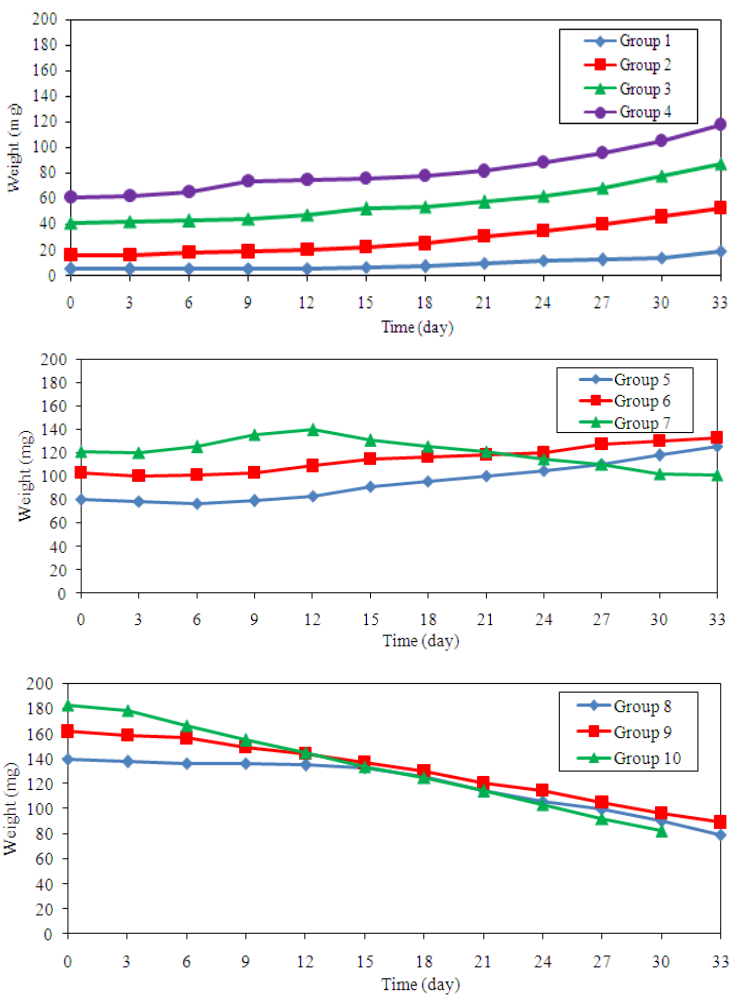

Fig. 3: Changes in the weight of larvae

The third set included groups 8-10 which had much older larvae (139.6-182.7 mg). The average weight of each of these 3 groups continued to decrease with time. These larvae were near the end of their larval stage and were headed for pupation which started on day 21, 12 and 9 for groups 8-10, respectively. Also emergence of adults from some of the pupae started on days 30, 21 and 18 for groups $8-10$, respectively.

Growth rate: The first 9 days were considered a period of adjustment to the new environment (slow growth or slow weight loss) in this study. This was followed by a period of real change in the weight of larvae (gain or loss). The growth rate was calculated by first linearizing the changes in weight for each group during this period as shown in Fig. 4. Then, the slope of the linear line was divided by the initial average weight of the larvae in each group to obtain the growth index. The results are presented in Table 6. A positive value of the growth rate indicates growth while a negative value indicates weight loss. The growth rate increased with the increase in body weight for groups 1-6 with group 5 showing the fastest growth rate $\left(1.88 \mathrm{mg} \mathrm{day}^{-1}\right)$. 


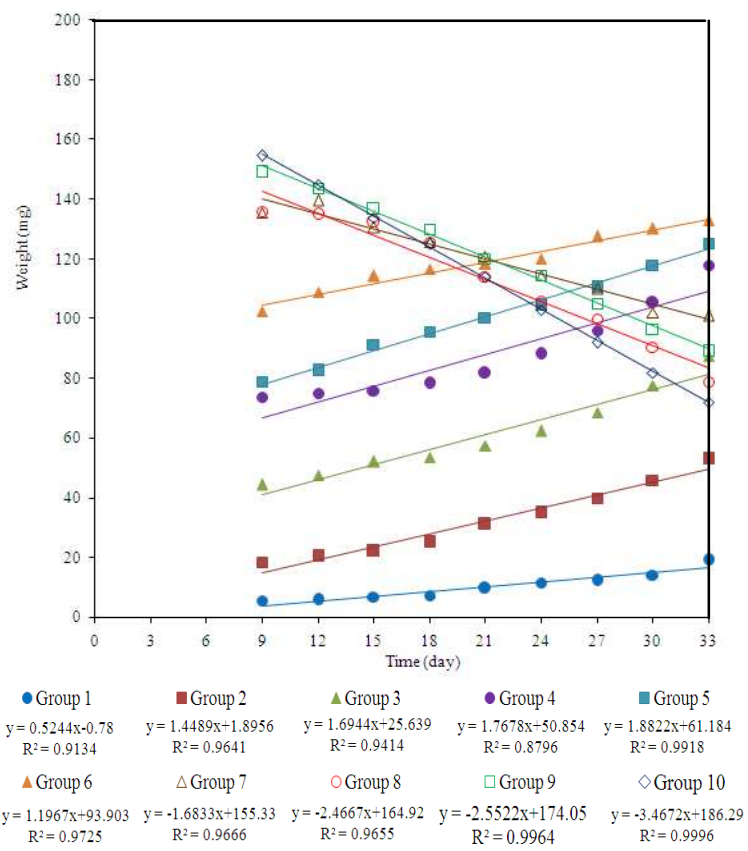

Fig. 4: Determination of growth rate (or weight loss rate)

Table 6: Growth rate and growth index

\begin{tabular}{lccll}
\hline Group & $\begin{array}{l}\text { Average } \\
\text { weight }(\mathrm{mg})\end{array}$ & $\begin{array}{c}\text { Weight range } \\
(\mathrm{mg})\end{array}$ & $\begin{array}{l}\text { Growth rate } \\
\left(\mathrm{mg} \mathrm{day}^{-1}\right)\end{array}$ & $\begin{array}{l}\text { Growth index } \\
\left(\mathrm{mg} \mathrm{mg}^{-1} \mathrm{day}^{-1}\right)\end{array}$ \\
\hline 1 & 4.8 & $4-6$ & 0.52 & 0.108 \\
2 & 16.0 & $14-18$ & 1.45 & 0.091 \\
3 & 41.4 & $40-44$ & 1.69 & 0.041 \\
4 & 61.1 & $59-65$ & 1.77 & 0.029 \\
5 & 80.3 & $78-85$ & 1.88 & 0.023 \\
6 & 103.0 & $100-105$ & 1.20 & 0.012 \\
7 & 121.1 & $118-125$ & -1.68 & -0.014 \\
8 & 139.6 & $138-143$ & -2.47 & -0.018 \\
9 & 161.5 & $158-166$ & -2.55 & -0.016 \\
10 & 182.7 & $179-186$ & -3.47 & -0.019 \\
\hline \multicolumn{7}{l}{- Indicates weight loss; Growth index = (Maximum weight of } \\
\multicolumn{5}{l}{ larva)/(initial weight of larva $\times$ time required for maximum growth) }
\end{tabular}

Table 7: Composition of larvae

\begin{tabular}{ll}
\hline Parameter & Value (\%) \\
\hline Moisture content & $58.1-61.5$ \\
Ash content (minerals) & $1.8-2.2(4.3-5.7)$ \\
Protein content & $24.3-27.6(63.31-68.87)$ \\
Fat content & $12.0-12.5(29.83-31.17)$ \\
\hline Values in parenthesis are calculated on dry basis
\end{tabular}

The rate of weight loss also increased as the body weigh increased for groups 7-10. The growth index decreased linearly (Fig. 5) with the increase in the body weight and had a positive value for groups 1-6 and a negative value for groups 7-10. The apparent weight loss for the older individuals was due to their entering the pupation stage. The critical weight beyond which individuals began to decrease in weight was 120-130 $\mathrm{mg}$. This suggests that an efficient production system would have the larvae harvested when they are at an average weight of $100-120 \mathrm{mg}$.

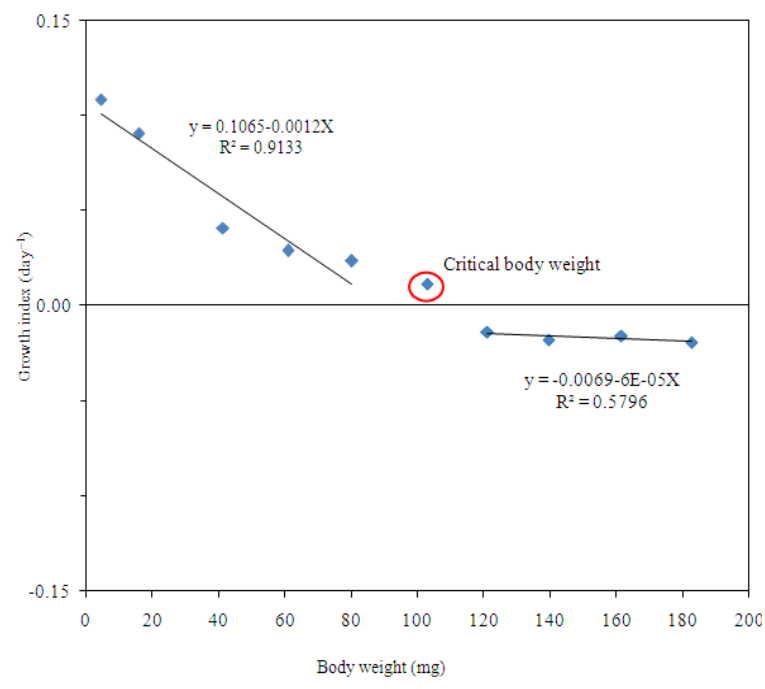

Fig. 5: Growth index

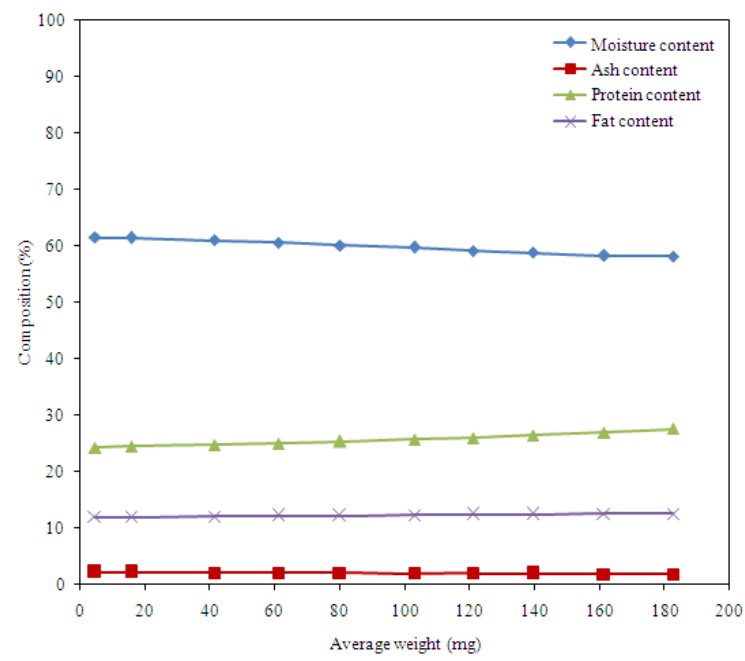

Fig. 6: Effect of body weight on the composition of the larvae

Larval composition: The results of the moisture, ash, protein and fat contents were calculated on live weight basis and are presented in Figure 6. The moisture content and the ash content decreases slightly (from 61.5-58.1\% and from $2.2-1.8 \%$, respectively) as the average body weight of the larvae increased from 4.8-182.7 mg. The crude protein and fat contents increased (from 24.3-27.6\% and from $12.0-12.5 \%$, respectively) as the average body weight of the larvae increased from 4.8-182.7 mg. On a dry wet basis, the ash, protein and fat contents of the yellow mealworms are in the ranges of 4.3-5.7, 63.3168.87 and $29.83-31.17 \%$, respectively (Table 7). 
Table 8: Amino acid profile in larvae

\begin{tabular}{lc}
\hline Amino acid & Yellow mealworm $(\mathrm{g} / 100 \mathrm{~g})$ \\
\hline Alanine & 6.8 \\
Arginine & 4.3 \\
Cysteine & 5.6 \\
Glycine & 2.0 \\
Glutamic & 12.3 \\
Histidine & 1.7 \\
Isoleucine & 4.8 \\
Leucine & 8.2 \\
Lysine & 5.3 \\
Methionine & 2.0 \\
Phenylalanine & 4.6 \\
Serine & 4.7 \\
Threonine & 4.0 \\
Tryptophan & 0.7 \\
Tyrosine & 4.0 \\
Valine & 6.4 \\
\hline
\end{tabular}

The quality of the protein, and thus the nutritional values, is determined by the amino acid composition ${ }^{[33]}$. The results of the amino acid profile are shown in Table 8. The yellow mealworm contains all the essential amino acids needed for human nutrition.

\section{DISCUSSION}

The high protein content of the mealworm larvae and the fact that this insect is easy to rear and maintain make the results of this study very interesting. The mealworms are large in comparison to other insects suggested for protein production and can, therefore, be harvested at an earlier stage of their development. The results indicate that the larvae must be harvested before they begin to prepare for the pupal stage, as they begin to lose weight at this time. The most efficient period of development for the mealworm is the early larval stage (at about 100-120 mg weight) after which the growth was found to cease and the larvae started to lose weight.

The adults in the main culture migrated to the potatoes and seemed to flourish due to higher moisture content. However, the adults in the growth experiment did not thrive as a source of moisture (potatoes) was not made available for them. The presence of material with high moisture content (potatoes) can encourage microbial growth and may result in the loss of the culture. In this study, only $10 \%$ mortality was observed in the older larvae (139- $182.7 \mathrm{mg}$ ). Thus, the moisture issue will present an important management problem for commercial production. A system where the eggs are separated from the adults and hatched in a separate chamber would help alleviate the danger of losing the larval population due to microbial infection (mould/fungus).

The high moisture content of the mealworms (58.1$61.5 \%)$ could cause storage and handling problems.
Drying and grinding the larvae would reduce them to an easily manageable form and would improve their marketability. Pirie ${ }^{[18]}$ outlined the following necessary steps to be taken to make a novel food such as insects acceptable: (a) obtaining knowledge of existing dietary patterns of the consumers, (b) identifying the type of food preparations in which the novel food can be incorporated, (c) developing and standardizing suitable recipes for utilizing the novel food, (d) introducing the acceptable preparations into homes and community feeding programmes, (e) imparting nutrition education to consumers on the benefits of the novel food and (f) popularizing the novel food through the press, radio, TV and other media.

Mass rearing of insects has been practiced for years. Bees are grown in large quantities for distribution as colonies to honey producers ${ }^{[34]}$. Boll weevils have been mass reared for pest control ${ }^{[35-38]}$. Mealworms have been produced on a commercial scale as food for birds and reptiles ${ }^{[28]}$. Some efforts have been made to produce flies from livestock waste for animal consumption ${ }^{[14-16,39]}$. It is, therefore, conceivable that insect farming will be a part of a new agricultural system. It will be possible in the near future to construct small but efficient insect farms that have high volumetric production rate of protein. Insects such as yellow mealworms are in size between SCP and farm animals, they yield structured animal protein, require much less energy for processing than SCP and less space than farm animals, still large enough to be reared and harvested using automated systems. They contain proteins (essential amino acids), lipids, minerals, vitamins $\left(\mathrm{E}\right.$ and $\left.\mathrm{B}_{2}\right)$ and energy ${ }^{[19,33,40]}$.

In the light of current protein deficiency and population growth, there is a need for novel protein sources as an alternative for meat production. These new protein sources should be safe, nutritious, flexible, reliable, and consumer accepted. It has been predicted that in the next decades about $40 \%$ of red bovine meat consumption will be replaced by novel protein sources such as insects ${ }^{[20]}$. The inexhaustible supply of low substrates (waste materials) can be used as a food source because the feed conversion efficiency of insects is quite high (more than five times that of beef) ${ }^{[40]}$. Since a wide variety of this substrate is available, materials which are not edible can be converted into human food by insects such as yellow mealworms. In addition, insects are fast growing organisms ${ }^{[40]}$, a characteristic that allow the design of a farm system that can respond to changes in demand. The integration of insects into the current agricultural production system will increase the complexity of the systems by creating symbiotic relationships with other species. 
This will improve the system efficiency and insure its sustainability.

\section{CONCLUSION}

Yellow mealworms of various sizes (4.8-182.7 mg) were successfully grown in a medium of wheat flour and brewer's yeast (95:5 by weight). There was an initial adjustment period (3-9 days) observed for all groups. During this period, the younger groups 1-4 (4.8-61.1 mg) grew slowly whereas the older groups 5$10(80.3-132.7 \mathrm{mg})$ lost weight. After this initial period, groups 1-6 started gaining weight but groups 7-10 continued to lose weight till the end of the experiment. The loss of weight in the older larvae was a result of them entering the pupation stage at an average body weight of 130.0-154.6 mg. The critical weight beyond which individual larvae began to decreases in weight was in the range of 120.0-130 mg. For the efficient production of insects the larvae should be harvested at 100-110 mg. The moisture and ash contents decreased (from 61.5-58.1 and 2.2-1.8\%, respectively) and the protein and fat contents increased (from 24.3-27.6 and $12.0-12.5 \%$, respectively) when the body weight increased from $4.8-182.7 \mathrm{mg}$. The protein and fat contents varied from 63.31-68.84 and 29.83-31.17\% (dry basis), respectively.

The yellow mealworms seem to be a promising source of protein for human consumption. To make insects commonly used as human food, it is necessary to develop the technology which will allow large scale productions at a reasonable cost. The system should be highly automated to allow the conversion of substrate into insect protein in a manner similar to the production of SCP. Thus, further research into raising them on a variety of low quality substances/wastes such as saw dust, waste paper, corn starch and potato flour is recommended. The future research should also investigate other parameters such as minerals, protein, fat, carbohydrate and vitamin contents of the feed as well as oxygen consumption, $\mathrm{CO}_{2}$ production and heat generation. This information will aid in the design of an optimum large scale production system.

The high moisture content of the worms (58.1$61.5 \%$ ) could cause storage and handling problems. Drying and grinding the larvae would reduce them to an easily manageable form and improve marketability. High moisture is required in the medium for adults to thrive but will present an important management problem for commercial production. A system in which eggs are separated from adults and hatched in separate chambers will help alleviate the danger of losing the larvae population due to microbial infection.
Mealworm recipes: Insects can deteriorate quickly just like meat that is left out on the kitchen counter. Before you begin whipping up delicious insect meal, you must kill the larvae by freezing them alive for $48 \mathrm{~h}$ in an airtight bag or container. Always keep them in the freezer until you are ready to use them. Dried larvae can be used in place of nuts, raisins and chocolate chips in many cookies, bread or dessert recopies. Powdered larvae can also replace part of the flour in cakes or pie crust. Barely thawed whole larvae can be added to sauces. The following recipes are modifications of those suggested by Taylor and Carter ${ }^{[41]}$.

\section{Mealworm appetizers: Ingredients:}

$\begin{array}{lll}1 & \text { tsp } & \text { Cayenne } \\ 1 / 2 & \text { tsp } & \text { Black pepper } \\ 1 / 3 & \text { Cup } & \text { Mealworm larvae, slightly thawed } \\ 2 & \text { tbsp } & \text { Butter } \\ 1 / 4 & \text { Cup } & \text { Margarine } \\ 5 & \text { tsp } & \text { Worcestershire sauce } \\ 11 / 4 & \text { tsp } & \text { Salt } \\ 1 / 4 & \text { tsp } & \text { Garlic powder } \\ 2 \frac{2}{3} & \text { Cup } & \text { Corn squares } \\ 2 \frac{2}{3} & \text { Cup } & \text { Rice squares } \\ 22 / 3 & \text { Cup } & \text { Wheat squares } \\ 1 & \text { Cup } & \text { Mixed nuts } \\ & 1 & \text { Cup pretzels }\end{array}$

Procedure: Place the first four ingredients together into a sauce pan. Sautee, stirring constantly, until mealworms are golden brown. Preheat oven to $120^{\circ} \mathrm{C}$ $\left(250^{\circ} \mathrm{F}\right)$. To prepare home mix melt the margarine in preheated roasting pan. Stir in the Worcestershire sauce, seasoned salt and garlic powder. Gradually add corn squares, rice squares, wheat squares, nuts and pretzels. Stir to coat evenly. Bake for 1 hour at $120^{\circ} \mathrm{C}$ $\left(250^{\circ} \mathrm{F}\right)$, stirring every $15 \mathrm{~min}$. Spread on absorbent paper to cool. Add the mealworms to the home mixture and serve. The combination provides extra nutrition, fiber, and an interesting texture.

\section{Mealworm cookies: Ingredients:}

$\begin{array}{ll}1 & \text { Cup } \\ 3 / 4 & \text { Cup } \\ 3 / 4 & \text { Cup } \\ 1 & \text { tsp } \\ 2 & \\ 11 / 4 & \text { Cup } \\ 1 & \text { tsp } \\ 1 & \text { tsp } \\ 11 / 2 & \text { Cup } \\ 1 / 2 & \text { Cup }\end{array}$

Softened butter or margarine White sugar Brown sugar Vanilla eggs All purpose flour Baking soda SALT Cups chocolate chips Crumbled dried mealworms 
Procedure: Place the cleaned and prepared insects on a cookie sheet and dry in oven for 1 hour at $100^{\circ} \mathrm{C}$ $\left(215^{\circ} \mathrm{F}\right)$. Preheat oven to $190^{\circ} \mathrm{C}\left(375^{\circ} \mathrm{F}\right)$. In a bowl, cream butter, white sugar, brown sugar, vanilla and eggs together on medium speed of an electric mixer until light and creamy. Combine flour, baking soda and salt and add to creamed mixture, beating on low speed until blended. Stir in chocolate chips and mealworms. Drop dough by heaping teaspoonfuls onto a greased cookie baking sheet, and bake at $190^{\circ} \mathrm{C}\left(375^{\circ} \mathrm{F}\right)$ for 8 $10 \mathrm{~min}$, or until light golden brown. Under bake for chewy cookies. Bake longer for crisp cookies.

\section{Mealworm Canapes: Ingredients:}

$\begin{array}{lll}1 / 3 & \text { Cup } & \text { Mealworm larvae, slightly thawed } \\ 2 & \text { Cloves } & \text { Finely chopped garlic } \\ 1 & \text { tsp } & \text { Tomato paste } \\ 1 & \text { tbsp } & \text { Olive oil } \\ 1 & \text { tsp } & \text { Lemon juice } \\ 1 & \text { tsp } & \text { Red wine vinegar } \\ 1 & \text { tsp } & \text { Freshly ground pepper } \\ 1 & \text { Loaf } & \text { French bread (cut into } 1.5 \mathrm{~cm} \text { slices) } \\ 1 & \text { Cup } & \text { Finely chopped fresh parsley }\end{array}$

Procedure: With a mortar and pestle or an electric blender at medium speed, mash the mealworms, garlic and tomato paste into a puree. Stirring constantly in the mortar (or with the blender running), add oil, lemon juice, red wine vinegar and pepper until smooth and creamy. Preheat oven to $200^{\circ} \mathrm{C}\left(390^{\circ} \mathrm{F}\right)$. Under the broiler, toast one side of the bread slices. Spread the untoasted side with the mixture. Place the bread slices on a baking sheet and bake at $200^{\circ} \mathrm{C}\left(390^{\circ} \mathrm{F}\right)$ for 10 min. Sprinkle with parsley and serve.

Sui Mai: Ingredients:

$\begin{array}{lll}1 & \text { cup } & \begin{array}{l}\text { Mealworms } \\ 4\end{array} \\ 4 & \text { tbsp } & \text { Green chestnuts chopped } \\ 1 / 2 & \text { cup } & \text { Bamboo shoots } \\ 1 & & \text { Egg } \\ 1 & \text { tsp } & \text { salt } \\ 21 / 2 & \text { tbsp } & \text { Soy sauce } \\ 2 & \text { tbsp } & \text { Sherry } \\ 1 & \text { tsp } & \text { Sugar } \\ 11 / 2 & \text { tsp } & \text { Corn starch } \\ 1 / 4 & \text { tsp } & \text { Pepper wonton wrappers } \\ 2 & \text { cup } & \text { Vegetable oil } \\ 1 & \text { tsp } & \text { boiling water }\end{array}$

$\begin{array}{lll}1 & \text { tsp } & \text { mustard } \\ 1 & \text { tsp } & \text { vinegar }\end{array}$

Procedure: Place mealworms in an electric blender and grind at medium speed until paste-like. While constantly mixing, add water chestnuts, mealworm paste, sliced green onions, bamboo shoots, egg, salt, soy sauce ( $1 / 2$ tbsp), sherry, sugar, corn starch and pepper. Fill center of wonton wrapper with 2 tsp of mixture. Fold wonton in shape of a triangle. Moisten finger tips and seal edges. Fold greased corners backwards and secure the ends with more water. Place oil in skillet and heat to about $175^{\circ} \mathrm{C}\left(350^{\circ} \mathrm{F}\right)$. Fry for about 5 min. To make dipping sauce, add boiling water to mustard, vinegar and the rest of the soy sauce (2 tbsp) and stir well on stove at low heat. Serve Sui Mai with dipping sauce.

\section{ACKNOWLEDGEMENT}

This research was supported by the National Science and Engineering Council (NSERC) of Canada.

\section{REFERENCES}

1. Bodwell, C.E., 1977. Evaluation of Proteins for Humans. AVI Publishing Company Inc., London, ISBN: 0870552155, pp: 327.

2. Pariser, E.R., M.B. Wallerstein, C.J. Corkery and N.L. Brown, 1978. Fish Protein Concentrate: Panacea for Protein Malnutrition. The MIT Press, Boston, Massachusetts, ISBN: 10: 0262160692, pp: 256.

3. Sikka, K.C., R. Singh, D.P. Gupta and S.K. Duggal, 1979. Comparative nutritive values of Fish Protein Concentrate (FPC) from different species of fish. J. Agric. Food Chem., 27: 946-949. http://www.ncbi.nlm.nih.gov/pubmed/546956

4. Zein, G.N., A.E.F. El-Bedawey, A.M. El-Sherbiney and F.M.A. Dawoud, 2004. Studies on fish protein concentrate and fish meal from river Nile bolti fish (Talapia nilotica). J. Food Chem., 29: 523-532. DOI: 10.1002/food.19850290530

5. Tannenbaum, S.R. and D.K. Wang, 1975. Single Cell Protein Production. The MIT Press, Boston, Massachusetts.

6. Ferrianti, M.P. and A. Fiechter, 1983. Production and Feeding of Single Cell Protein. Applied Science Publications, London, ISBN: 10: 0853342431.

7. WHO/FAO, 2007. Protein and Amino Acid Requirements for Human Nutrition. World Health Organization/Food and Agricultural Organization of the United Nations WHO Press, New York. http://whqlibdoc.who.int/trs/WHO_TRS_935_eng.pdf 
8. Bodenheimer, F.S., 1951. Insects as Human Food: A Chapter of the Ecology of Man. W. Junk Publishers, The Hague, pp: 352.

9. Taylor, R.L., 1975. Butterflies in my Stomach: Insects in Human Nutrition. Woodbridge Press Publishing Company, London, ISBN: 10: 0912800186.

10. Holt, V.M., 1969. Why not Eat Insects? Classey Publishing Ltd., England, pp: 99.

11. DeFoliart, G.R., 1999. Insects as food: Why the western attitude is important. Ann. Rev. Entomol., 44: 21-50.

http://www.ncbi.nlm.nih.gov/pubmed/9990715

12. USFDA., 2005. The food defects action levels United States food and drug administration. http://www.cfsan.fda.gov/ dms/dalbook.html

13. Kurtz, O.L. and K.L. Harris, 1962. Microanalytical Entomology for Food Sanitation Control. Association of Official Agricultural Chemists, Washington DC., pp: 576.

14. Burchell, R.L., 1989. Production of a protein substrate from poultry manure through the intensive production of insects final design project report. Technical University of Nova Scotia, Halifax, Nova Scotia.

15. Booram, C.V., G.L. Norton, R.W. Baker and O.M. Hale, 1976. The value of Hermetia illucens as an alternative protein source. ASAE Technical Paper No. 75-4563 ASAE, St. Joseph, Illonois.

16. Eby, I.T. and W.L. Dandy, 1962. An attempt to mechanized nutrient recovery from animal waste by the use of house fly larvae. Technical Report No. 20705 Beltsville Agricultural Research Center, Beltsville, Maryland.

17. Steinhouse, E.A., 1967. When an insect dies bulletin of the entomological. Soc. Am., 10: 199-210.

18. Pirie, N.W., 1975. Food Protein Source. Cambridge University Press, Cambridge, ISBN: 0521205883, pp: 260.

19. Bukkens, S.G.F., 1997. The nutritional value of edible insects. Ecol. Food Nutr., 36: 287-319. http://cat.inist.fr/?aModele $=$ afficheN\&cpsidt $=2097$ 512

20. Verkerk, M.C., J. Tramper, J.C.M. Van Trijp and D.E. Marlens, 2007. Insect cells for human food. Biotechnol. Adv., 25: 198-202. DOI: 10.1016/j.biotechadv.2006.11.004

21. Hyde, N., 1984. The queen of textile. Natl. Geograp., 168: 2-49. http://www.bcin.ca/Interface/openbcin.cgi?submit= submit\&Chinkey=42173

22. Giroux, M., 1996. Raising mealworms. Food Insect News Lett., 9: 1-7.
23. Cotton, R.T., 1963. Pests of Stored Grain and Grain Products. Burgess Publishing Company, Minneapolis, Minnesota, pp: 318.

24. Metcalf, C.L. and W.P. Flint, 1962. Destructive and Useful Insects. 4th Edn., McGraw Hill, Beck Company, Toronto, ISBN: 10: 0070416583, pp: 1099.

25. Campbell, J.M., D.B. Loyons and M.J. Sarazin, 1989. Canadian Beetles (Coleoptera): Injuries to Crops, Ornamentals, Stored Products and Buildings. Research Branch, Agricultural Canada, Ottawa, Ontario, ISBN: 0660129671, pp: 491.

26. Monro, H.A.V., 1969. Insect Pests in Cargo Ships. Research Branch, Agriculture Canada, Ottawa, Ontario, pp: 39.

http://openlibrary.org/b/OL4802885M/Insect_pests _in_cargo_ships

27. Sinha, R.N. and F.L. Walters, 1985. Insect Pests of Flour Mills, Grain Elevators and Feed Mills and their Control. Research Branch, Agriculture Canada, Ottawa, Ontario, ISBN: 13: 9780660117485.

28. Ebeling, W., 1975. Urban entomology, pests of stored food products.

http://www.entomology.ucr.edu/ebeling/

29. Gibson, R., 2009. The multipurpose mealworm Leapingfromthebox.com. http://www.leapingfromthebox.com/art/rlg/mealwo rms.html

30. Lyons, W., 1991. Rearing Mealworms Fact Sheet. Entomology Center, Ohio State University, Columbia, Ohio.

31. APHA., 1990. Standard Methods for Examination of Water and Wastewater. American Public Health Association, Washington DC.

32. AOAC., 1975. Official Methods of Analysis of the Association of Official Agricultural Chemistry. Washington, DC., pp: 1015.

33. DeGuevara, L.O., P. Padilla, L. Garcia, J.M. Pino and J. Ramos-Elorduy, 1995. Amino acid determination in some edible Mexican insects. Amino Acids, 9: 161-173. DOI: 10.1007/BF00805837

34. Kok, R., U.S. Shivhare and K. Lomaliza, 1991. Mass and component balances for insect production. Can. Agric. Eng., 33: 185-192.

35. Miller, J.A., C.D. Schmidt and J.L. Eschle, 1975 Systems for large scale rearing of hornfly Haematobia irritans. ASAE Technical paper No. 75.415 ASAE, St. Joseph Illinois.

36. Harrel, E.A., W.D. Perkins and A.N. Sparks, 1980. Improved equipment and techniques for mechanizing the boll weevil larval rearing system. Trans. ASAE., 23: 1554-1556. 
37. Garth, C.W. and W.E.G. King, 1981. Diet dispenser for a multiple insect species rearing program. Trans. ASAE., 24: 194-196.

38. Webb, J.C., H.R. Agee, N.C. Leppla and C.O. Calkins, 1981. Monitoring insect quality. Trans. ASAE., 24: 476-479.

39. Morgan, N.O. and H.J. Eby, 1975. Fly protein production from mechanically mixed animal wastes Israel. J. Entomol., 10: 73-81.
40. DeFoliart, G.R., 1992. Insects as human food: Gene DeFoliart discusses some nutritional and economical aspects. Crop Prod., 11: 395-399. DOI: 10.1016/0261-2194(92)90020-6

41. Taylor, R.L. and B.J. Carter, 1992. Entertaining with Insects, or, the Original Guide to Insect Cookery. Salutek Publishing Co., Anaheim, California, ISBN: 0964583801, pp: 160. 